\title{
An Empirical Study on the Trade Impact of Cross border E- commerce on ASEAN and China under the Framework of RECP
}

\author{
Wang Guanhui $^{1^{*}}$, Cao Zengyu ${ }^{1}$ \\ ${ }^{1}$ School of International Business, Tianjin Foreign Studies University, Tianjin, 300204, China
}

\begin{abstract}
As an indispensable part of future global trade, the cross-border e-commerce will change the form and volume of the current global trade with globalization. Taking China and ten ASEAN countries as the research object, this paper empirically tests whether the cross-border e-commerce under the RCEP framework will affect the trade scale between China and ten ASEAN countries through the trade gravity model. As the research suggests, the impact of GDP and the Internet popularity on the trade scale of different ASEAN countries and China is not the same. Malaysia, Vietnam, Singapore, Thailand and other countries have larger trade volume with China due to economic factor, Internet, geographical location and other factors, while Brunei and Laos, which are closer to China with smaller economic volume, have more obvious shortcomings and are less related to the trade with China.
\end{abstract}

\section{Introduction}

In the era of digital economy, the rise of cross-border Ecommerce makes the countries that participate in international trade in a more efficient way to achieve mutual benefit. The RCEP signed in November 2020 will build a bridge in the Asian market with huge development potential, connect the ten ASEAN countries and China, Japan, South Korea, Australia and New Zealand, and push the Asian economy by eliminating the trade barriers and developing themselves integrally.For the ten ASEAN countries with large potential, China in RCEP will greatly promote the trade prosperity of Southeast Asia. The data in "China's Cross-border E-commerce Market Report in 2019" show that the penetration rate of its cross-border ecommerce in 2019 is 33.29\%, which is 3.79\% higher than
$29.5 \%$ in 2018. In 2019, the scale of cross-border ecommerce transactions accounted for $33.29 \%$ of 31.54 trillion yuan, China's total import and export value . Compared with the previous year, the penetration rate has increased steadily, and the cross-border e-commerce has played a more prominent role in boosting the development of traditional foreign trade. On the other hand, " The Statistical Yearbook of China and ASEAN in 2019"(with data from 2014 to 2018) shows that China is the largest exporter of Laos, Myanmar and other countries for three consecutive years, and the largest importer of six countries including Singapore, Vietnam and Thailand for five consecutive years. This shows that most ASEAN countries are highly dependent on China in both import and export. The import and export volume of goods between China and the ten ASEAN countries from 2010 to 2019 is shown in Figure 1.

*Corresponding author’s e-mail: wgh@tjfsu.edu.cn 


\section{The total value of imports and exports of goods \\ between China and the ten ASEAN countries from \\ 2010 to 2019 (unit: ten thousand yuan)}

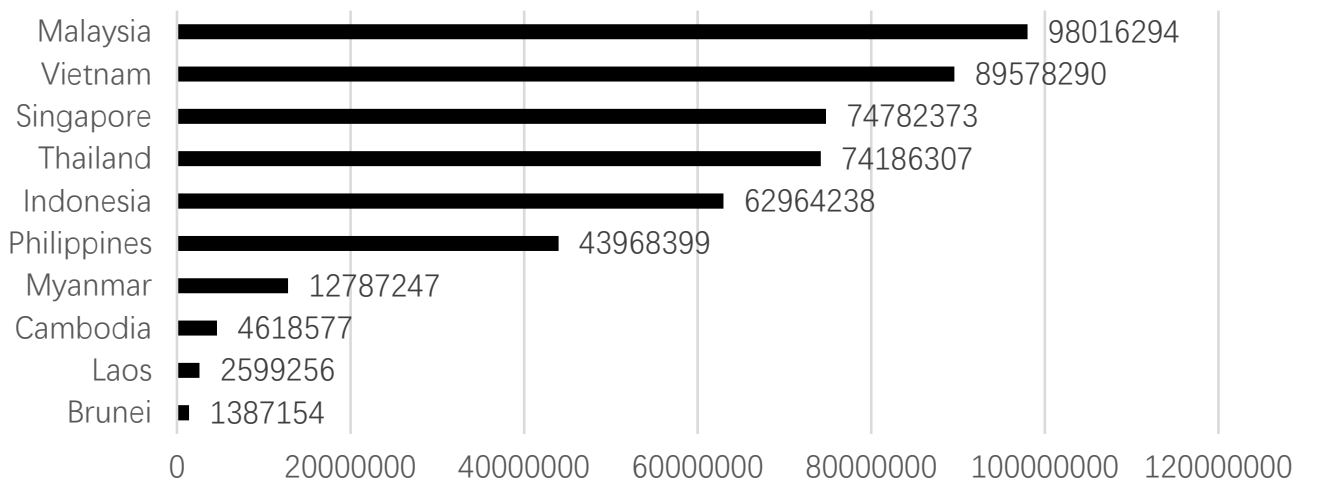

Figure 1. total import and export volume between ten ASEAN countries and China from 2010 to 2019

\section{Model and Data Description}

According to the traditional trade gravity model (1), we can know that the trade volume between the two countries is directly proportional to the GDP of the two countries, and is inversely proportional with the distance between the two countries .Among them, $\mathrm{IMP}_{\mathrm{ij}}$ represents the volume of trade between countryi and countryj, GDP represents the GDP of countryi, GDP $_{j}$ represents the GDP of countryj, and $\mathrm{DIS}_{\mathrm{ij}}$ represents the linear distance between two countries.

$$
I M P_{i j}=\frac{G D P_{i} \times G D P_{j}}{D I S_{i j}}
$$

This paper selects the data of ten ASEAN countries including Indonesia, Cambodia, Myanmar, Laos, Vietnam, Brunei, Thailand, Singapore, Philippines and Malaysia from 2010 to 2019, including the import and export volume of each country with China, the GDP of each country, the linear distance between its capital and Beijing, the total population and the Internet penetration rate to improve the traditional trade gravity model. Its linear model is shown in (2), and its variables definition and the data sources are shown in Table 1.

$$
\begin{aligned}
\ln (\text { Trade })= & \alpha_{0}+\alpha_{1} \ln \left(\mathrm{GDP}_{\mathrm{c}}\right)+\alpha_{2} \ln (\mathrm{GDP})+\alpha_{3} \ln (\mathrm{Pop})+\alpha_{4} \ln (\text { Internet })+ \\
& \alpha_{5} \ln (\text { Distance })+\alpha_{6} \text { Bor }+\alpha_{7} \text { Develop }+\beta
\end{aligned}
$$

Table1. variable definition and data source

\begin{tabular}{|c|c|c|}
\hline $\begin{array}{c}\text { Variable } \\
\text { name }\end{array}$ & Representative meaning & data sources \\
\hline Trade & Total imports and exports of ASEAN countries and China & $\begin{array}{c}\text { The Statistical Yearbook of } \\
\text { China }\end{array}$ \\
\hline GDPc & China's GDP & World Bank Database \\
\hline GDP & GDP of the ASEAN countries & World Bank Database \\
\hline Pop & Population of the ASEAN countries & World Bank Database \\
\hline Distance & $\begin{array}{c}\text { The linear distance between the capitals of ASEAN countries } \\
\text { and Beijing, the capital of China }\end{array}$ & CEPII \\
\hline Internet & $\begin{array}{c}\text { Internet penetration rate (the proportion of Internet users in } \\
\text { the total population of country } i \text { ) }\end{array}$ & World Bank Database \\
\hline Bor & Whether ASEAN countries border on China & Google Maps \\
\hline Develop & Whether ASEAN countries are developed & Wikipedia \\
\hline
\end{tabular}

\section{Analysis of the Regression}

First, after LM Test on all data, the result shows that we strongly reject the hypothesis that "there is no individual random effect", that is to say, we should choose "random effect" for regression analysis between "random effect" and "mixed effect". All regression results are shown in Table 2. The second column of the table shows the regression results of the whole samples of ten ASEAN countries. Among the ten ASEAN countries, Myanmar, Laos and Vietnam are the countries bordering on China, as 
the third column of the table will regress them. Among the ten ASEAN countries, only Brunei and Singapore are developed countries, which are regressed in the fourth column of the table.

Generally speaking, the trade volume between the two countries is directly proportional to the GDP of the two countries, and if the GDP of an ASEAN country increases by $1 \%$, the import and export volume of China and that country will increase by $1.255 \%$, which means that the GDP is still the most intuitive indicator of a country's productivity. In contrast, the increase of China's GDP on the trade volume between the two countries is not as significant as the increase in the GDP of ASEAN countries. From the data alone, China's total GDP is 10 to 1000 times that of ASEAN countries. Considering China's rich industries and huge economic volume, the effect of the national income growth of ASEAN countries will be more obvious. Of course, the three countries bordering on China, due to their limited economic size, especially Laos, its agriculture being their pillar industries, need to be more industrialized. Therefore, at present, the three countries mainly import mechanical and electrical products, industrial products and other goods that demand manufacturing and processing technology from China. The growth of GDP means that the same time when they are seeking development they are also upgrading the level of science and technology and expanding the local production of the above categories, so that they will not have to import a large number of such goods from China.

Table2. results of stochastic utility regression

$\mathrm{z}$-statistics in parentheses

$* * * \mathrm{p}<0.01, * * \mathrm{p}<0.05, * \mathrm{p}<0.1$

\begin{tabular}{|c|c|c|c|}
\hline & $\begin{array}{l}\text { Full sample } \\
\text { regression }\end{array}$ & $\begin{array}{l}\text { Regression only on samples } \\
\text { of countries bordering China }\end{array}$ & $\begin{array}{l}\text { Regression on samples of } \\
\text { developed countries only }\end{array}$ \\
\hline VARIABLES & LTrade & LTrade & LTrade \\
\hline LGDPc & $\begin{array}{c}0.11 \\
(1.09)\end{array}$ & $\begin{array}{c}1.944^{* *} \\
(2.24)\end{array}$ & $\begin{array}{c}2.463^{* *} \\
(2.44)\end{array}$ \\
\hline LGDP & $\begin{array}{l}1.255^{* * * *} \\
(9.57)\end{array}$ & $\begin{array}{l}-0.288 \\
(-0.35)\end{array}$ & $\begin{array}{l}0.273 \\
(0.57)\end{array}$ \\
\hline LPop & $\begin{array}{l}-0.373 \\
(-1.47)\end{array}$ & $\begin{array}{l}1.181^{*} \\
(1.71)\end{array}$ & $\begin{array}{c}-11.803^{*} \\
(-1.95)\end{array}$ \\
\hline Linternet & $\begin{array}{c}0.132 * * * \\
(3.89)\end{array}$ & $\begin{array}{l}-0.033 \\
(-0.33)\end{array}$ & $\begin{array}{l}-1.111 \\
(-1.37)\end{array}$ \\
\hline LDistance & $\begin{array}{l}-0.458 \\
(-0.24)\end{array}$ & $\begin{array}{c}-6.733 * * * \\
(-2.67)\end{array}$ & $\begin{array}{l}242.733 * * \\
(2.09)\end{array}$ \\
\hline Bor & $\begin{array}{l}0.456 \\
(0.61)\end{array}$ & & - \\
\hline Develop & $\begin{array}{l}-1.232 \\
(-1.14)\end{array}$ & - & \\
\hline Constant & $\begin{array}{r}-11.027 \\
(-0.68)\end{array}$ & $\begin{array}{l}-4.233 \\
(-0.64)\end{array}$ & $\begin{array}{c}-1,917.830^{* *} \\
(-2.12)\end{array}$ \\
\hline Observations & 100 & 30 & 20 \\
\hline Number of code & 10 & 3 & 2 \\
\hline
\end{tabular}

In the ten ASEAN countries, $1 \%$ increase in the overall Internet penetration rate will cause an $0.132 \%$ increase the import and export volume between China and the country. the Internet penetration rate of Malaysia and Thailand grows rapidly from 2010 to 2019. As a developing country not bordering China yet on the same continent, Thailand's trade volume between China and Thailand has increased steadily in the past ten years. In particular, Malaysia's Internet penetration rate is as high as $84.2 \%$, ranked only after Brunei and Singapore. Although it is not bordering on China, the trade between China and Malaysia ASEAN ranked the first among the ten ASEAN countries.

The straight-line distance between the capitals of the two countries is an index to measure the trade cost of the two countries. Obviously, the increase of the straight-line distance between the two countries will bring certain obstacles to the trade between the two countries. Considering the geographical factors, if the two trading sides are not adjacent, and the shipping route is relatively long, the cheaper rail transportation and shipping will be affected to a certain extent, and the increase of the transportation cost will restrain the trade of the common goods in two countries. As the regression suggests, for each 1\% increase in the linear distance between Myanmar and Beijing, Laos and Beijing, or between Vietnam and Beijing, the import and export volume of each of them and China will decrease by $6.733 \%$, so the inhibitory effect is obvious. 


\section{Conclusion and Suggestion}

By extending the trade gravity model and introducing explanatory variables such as the Internet penetration rate, this paper evaluates the impact of the development of cross-border e-commerce under the RCEP framework on the trade between the two countries. The conclusion is that, in the case of the huge economic gap between the ten ASEAN countries and China, the promotion of the GDP of the ten ASEAN countries has a more obvious role in promoting the trade between the two countries; for the ASEAN countries closer to China, the promotion of the Internet penetration rate has limited influence on the promotion of the trade between the two counturies, because on the one hand, their economic development is relatively low, on the other hand, similar geographical location will bring about similar demand, especially in cross-border e-commerce industry.Based on this, the following suggestions are made.

Because of their high-levelled development and close trade with China, the countries such as Singapore, Malaysia and Singapore have formed a certain scale of cross-border e-commerce market. 1. For example, Shopee, an e-commerce enterprise in Singapore in range of Taiwan of China and many countries including Malaysia, Thailand, Indonesia, Vietnam and the Philippines, relies on its selfbuilt logistics and its parent company's Seamoney, and forms a relatively complete cross-border e-commerce system. Singapore, Malaysia and other countries should actively seek complementarity with China's market, and make use of China's vast market to maintain their high influence in Southeastern Asia market. In addition, according to Chapter 12 of RCEP, they should continuously improve efficiency and reduce transaction risk in the cross-border e-commerce transaction, and pay attention to information security and information protection.

2. Countries like Laos, Myanmar and Cambodia should first expand the industries that can form comparative advantages over China's market, which are close to yet not homogeneous with China's market, and have trade exchanges after specializing their production respectively, so as to maximize the scale efficiency. As RCEP member countries continue to eliminate the tariff and non-tariff trade barriers and subsidies for agricultural exports, the ASEAN countries will be greatly supported and benefit from it. Secondly, it will be easy for the ASEAN countries with a certain economic basis to integrate into the development of cross-border ecommerce than those with poor economy by improving the comprehensive quality of their citizens and raising the level of education so as to increase the proportion of the Internet users to the total population.Therefore, they are also more capable of their infrastructure and management capabilities in bonded warehouses and international transshipment, and with the development of Internet communication and transmission technology, they will be able to implement their own paperless trade and popularize the digital information exchange and storage such as electronic signatures, continuously develop their own online payment system, and actively carry out foreign trade with other countries. In addition, Brunei, which has a relatively developed economy, should gradually reduce its dependence on natural resources and seek sustainable and more competitive industries for mutual benefit with RCEP members.

3. China should play a leading role in all the member countries and make full use of the mature overseas outsourcing channels, and the rich resources and experience of Alibaba, Jingdong and other domestic ecommerce giants to provide convenience for the ASEAN countries. For example, to set up overseas branches in the ASEAN countries, or to finance the potential small-sized and medium-sized enterprise engaged in cross-border ecommerce in ASEAN.

\section{Acknowledgements}

The project is supported by Humanities and Social Sciences in Tianjin Universities No. 20132127.

\section{References}

1. MA Shu-zhong, PAN Gang-jian ,From Cross-border Ecommerce to Global Digital Trading: A Reexamination Perspective from Global Transmission of COVID-2019, [J].Journal of Hubei University ( Philosophy and Social Science)

2. Gomez-Herrera E, Martens B, Turlea G. The drivers and impediments for cross-border ecommerce in the EU[J].Information Economics \& Policy, 2014, 28(1)

3. Ping Liqun ,The Pace of Asia-Pacific Economic Integration: with the Centre of RCEP [J]Asia-Pacific Security and Maritime Affairs ,2020,06,(111)

4. Zhang Yan, Reconstruction of RCEP Regional Value Chains and China\&apos;s Policy Choice: Based on the B\&R Construction, [J].Asia-pacific Economic Review,2020,05,(14)

5. ASEAN, China, Japan, South Korea, Australia, New Zealand, Regional Comprehensive Economic Partnership, 2020,11

6. Cui Xin-sheng, Li Fang Impact of Trade Facilitation on Imports of China-Empirical Analysis Based on Gravity [J].Model On Economic Problems,2020, 7(123)

7. Zhang Peng-fei ,Tang Yun-yi, The Impact of Digital Service Level on International Bilateral Trade along the Belt and Road-An Empirical Study Based on Asian Countries, [J].Journal of Shanghai University of International Business and Economics,2020,27(03)

8. LI Hao, Pan Xiao-fang, Study on the Impacting Factors on India\&apos;s Trade after Joining RCEP Based on Gravity Model, [J].Asia-pacific Economic Review,2016,05,(17)

9. Chen Shu-mei , Ni Ju-hua ,The Economic Effects of China\&apos;s Participation in RCEP: Based on the GATP Model [J].Asia-pacific Economic Review , 2014,02(125) 